\title{
EFFECT OF HISTAMINE ON CALCIUM MOVEMENT IN GUINEA PIG TAENIA COLI
}

\author{
Tetsuyuki NASU, Hideaki KARAKI, Miyoshi IKEDA and \\ Norimoto URAKAWA \\ Department of Veterinary Pharmacology, Faculty of Agriculture, University \\ of Tokyo, Bunkyo-ku, Tokyo
}

Received for publication March 30,1971

Calcium ions are known to play an important role in a contraction of smooth muscle. However, as reviewed by Lüllmann (1), no correlation has been found between tissue $\mathrm{Ca}$ content or $\mathrm{Ca}$ fluxes and the contractile response of the smooth muscle to various stimulants.

In guinea pig taenia coli, it was shown that cellular $\mathrm{Ca}$ fraction of relatively tightly bound form increase during contraction induced by barium or high concentration of potassium and decreased during the abolition of tension development by various inhibiting factors, and suggested that the shift of $\mathrm{Ca}$ into the relatively tightly bound fraction within the cell might have a concern with the tension development (2-5).

In this paper, it was attempted to make clear an effect of histamine on $\mathrm{Ca}$ exchange of smooth muscle in absence or presence of antihistamine, and the above suggestion based on the nonspecific smooth muscle stimulants was confirmed in the experiments using the specific smooth muscle stimulant.

Some of this work has already been briefly reported (6).

\section{METHODS}

Strips of taenia coli were isolated from white male guinea pigs, and immersed in the Tyrode solution oxygenated with $95 \% \mathrm{O}_{2}$ and $5 \% \mathrm{CO}_{2}$ at $37^{\circ} \mathrm{C}$. The Tyrode solution had the following composition $(\mathrm{mM}) ; \mathrm{NaCl} 136.8, \mathrm{KCl} 2.7, \mathrm{CaCl}_{2} 2.5, \mathrm{MgCl}_{2} 1.0, \mathrm{NaH}_{2}$ $\mathrm{PO}_{4}$ 0.4, $\mathrm{NaHCO}_{3} 11.9$ and glucose 5.5. Isotonic- $40 \mathrm{mM} \mathrm{K}$ (high-K) solution was made by replacing $40 \mathrm{mM} \mathrm{NaCl}$ by equimolar $\mathrm{KCl}$.

Tension: The contractile responses were recorded isometrically by a strain-gauge transducer (Nihon Kohden).

Tissue $\mathrm{Ca}$ : Muscles equilibrated for 40 minutes in normal Tyrode solution were treated in a medium containing histamine at a concentration of $5.4 \times 10^{-6} \mathrm{M}$ or high- $\mathrm{K}$ solution. In case of antihistamine-treatment, $3.3 \times 10^{-8} \mathrm{M}$ tripelennamine was applied to the muscles at the 15 th minutes before the application of histamine or high-K solution. A certain period after the application of histamine or high- $\mathrm{K}$ solution, the strips were re-

A part of this work was supported by grants from Ministry of Education, Japan. 
moved from the bath. Then the strips were drawn across a sheet of filter paper to remove adhering solution, weighed, ashed in a furnace at $550^{\circ} \mathrm{C}$ and tissuc $\mathrm{Ca}$ content was determined by an atomic absorption spectrophotometer (Perkin-Elmer Model 303).

${ }^{45} \mathrm{Ca}$ uptake: After pretreatment, muscles were soaked in a solution with tracer amount of ${ }^{45} \mathrm{Ca}$ and histamine or high- $\mathrm{K}$ solution. In some experiments, ${ }^{45} \mathrm{Ca}$ was added 15 or 30 minutes after the addition of histamine. Strips were treated in the same manner as tissue $\mathrm{Ca}$ determination and radioactivity was counted by a gas flow counter (Aloka Window Type Model PS-13).

${ }^{45} \mathrm{Ca}$ efflux: Muscles were treated for 2 hours in $5 \mathrm{ml}$ radioactive Tyrode solution containing ${ }^{40} \mathrm{Ca}(20 \mu \mathrm{Ci} / \mathrm{ml})$. After loading the muscles were rinsed succsessively in a series of test lubes with nonradioactive Tyrode solution at one minute interval. At the end of the experiment, the radioactivities in the effluent and the muscle were counted. The rate of ${ }^{45} \mathrm{Ca}$ efflux was calculated from the radioactivity in each lest tube and was plotted as a fraction of the initial rate. The amount of ${ }^{45} \mathrm{Ca}$ remaining in the muscle was also plotted.

Tightly bound fraction: As the intracellular $\mathrm{Ca}$ in taenia coli could not be divided into fractions from the ${ }^{46} \mathrm{Ca}$ efflux curve $(3,7)$, the $\mathrm{Ca}$ fraction which did not exchange within 4 minutes has been tentatively named as the "tightly bound fraction (TBF)". TBF was estimated from ${ }^{45} \mathrm{Ca}$ uptake (4 minutes wash) experiment. At the end of 15 or 30 minutes incubation, the muscle was washed three times during 4 minutes period with Tyrode solution of the same chemical composition as the incubation medium.

Extracellular space: Extracellular space was measured using ${ }^{14} \mathrm{C}$-sorbitol (4).

\section{RESULTS}

Tension changes: Fig. 1 depicts the typical tension changes seen after application of Tyrode solution containing $5.4 \times 10^{-5} \mathrm{M}$ histamine or high- $\mathrm{K}$ solution.

Hexamethonium at a concentration of $3.7 \times 10^{-6} \mathrm{M}, 3.1 \times 10^{-7} \mathrm{M}$ tetrodotoxin, $2.8 \times$ $10^{-6} \mathrm{M}$ atropine or $2.9 \times 10^{-6} \mathrm{M}$ scopolamine inhibited neither the action of histamine nor high-K solution. However, when the muscles were pretreated with $3.3 \times 10^{-6} \mathrm{M}$ tri-

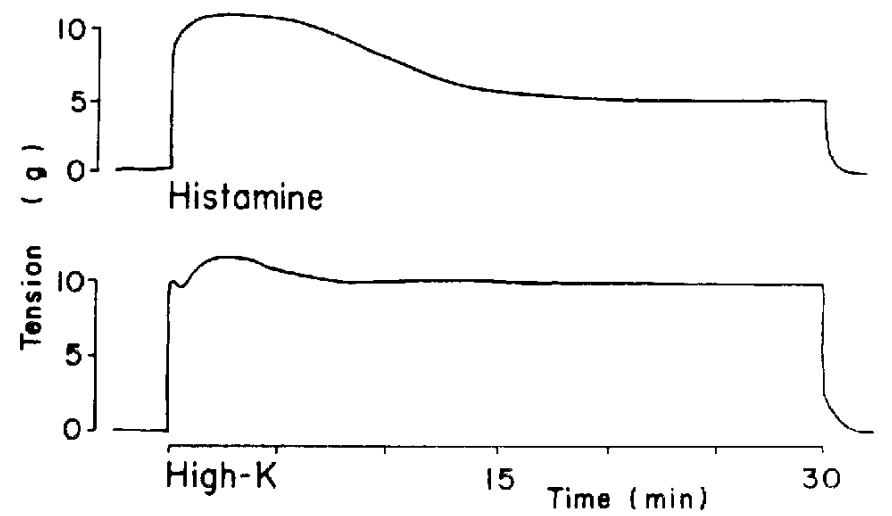

FIG. 1. Tension change curves of tacnia coli treated with $5.4 \times 10^{-6} \mathrm{M}$ histamine or high-K (40 mm, isotonic) solution. 
pelennamine, the antihistamine prevented the effect of histamine without changing the effect of high-K solution. These results are consistent with the data by Akubue (8) suggesting that the action of histamine on the tacnia coli of guinea pig resulted from the stimulation of specific receptors sited on the smooth muscle.

The noxt series of experiments were made to determine the external $\mathrm{Ca}$ dependence of the response of taenia coli to histamine. The muscles were kept in low Ca medium (1.25 or $0.25 \mathrm{mM} \mathrm{Ca}$ ) for 20 minutes and then histamine was added. Histamine-induced tension declined according to the decrease of $\mathrm{Ca}$ concentration in the medium. In $\mathrm{Ca}$ depleted medium, no response was observed in the presence of histamine and restoration of $\mathrm{Ca}$ was followed by an immediate contraction of the muscle.

Tissue $\mathrm{Ca}$ : Ca content of the muscle in normal Tyrode solution was $4.8 \pm 0.2 \mathrm{mEq}$ / $\mathrm{Kg}$ wet tissue (8) and the value did not change significantly throughout the period of observation. In the presence of histamine, tripelennamine or both histamine and triplennamine, Ca content did not differ significantly from control value (Fig. 2).

In high-K solution, tissue $\mathrm{Ca}$ content increased gradually to $5.6 \pm 0.1 \mathrm{mEq} / \mathrm{Kg}$ wet tissue (11) during 30 minutes (Fig. 2), which was in agreement with the previous data (4. 5). The tripelennamine treatment did not modify the increase in tissue $\mathrm{Ca}$ content of the muscle treated with high-K solution.
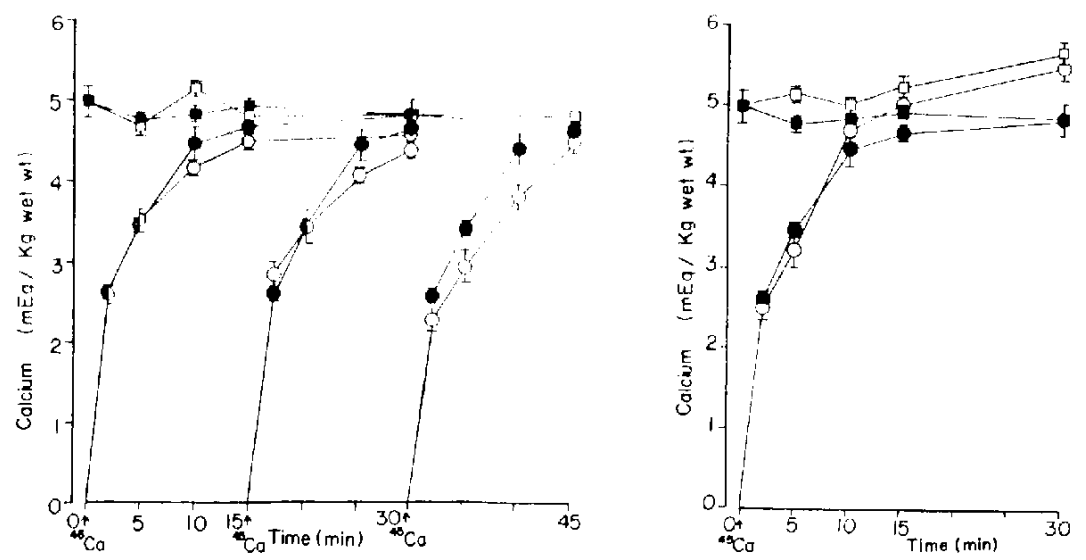

FiG. 2. Changes in tissue $\mathrm{Ca}$ and ${ }^{45} \mathrm{Ca}$ uptake of taenia coli in the presence of $5.4 \times$ $10^{-6} \mathrm{M}$ histamine (left) and high-K $(40 \mathrm{~mm}$, isotonic) solution (right). Histamine or high-K solution was added at time 0 . Each point in graph represents the mean of 6 to 20 experiments. Standard errors of means are also noted.

Tissue $\mathrm{Ca}\left([],{ }^{45} \mathrm{Ca}\right.$ uptake ( $)$ ) in Tyrode solution without (filled symbols) and with histamine or high-K solution (open symbols).

${ }^{45} \mathrm{Ca}$ uprake: ${ }^{45} \mathrm{Ca}$ uptake in the muscles are shown in Fig. 2. The figure represents that the cellular $\mathrm{Ca}$ mostly exchanges with extracellular ${ }^{45} \mathrm{Ca}$ within 15 minutes. ${ }^{45} \mathrm{Ca}$ uptake of the muscle did not differ from control values either when ${ }^{45} \mathrm{Ca}$ was added simultancously with histamine or 15 minutes later than the addition of histamine. When ${ }^{45} \mathrm{Ca}$ was added 30 minutes after the addition of histamine, the slight depress in ${ }^{45} \mathrm{Ca}$ uptake was observed (Fig. 2).

The ${ }^{45} \mathrm{Ca}$ uplake did not change from the value obtained in the normal Tyrode solu- 

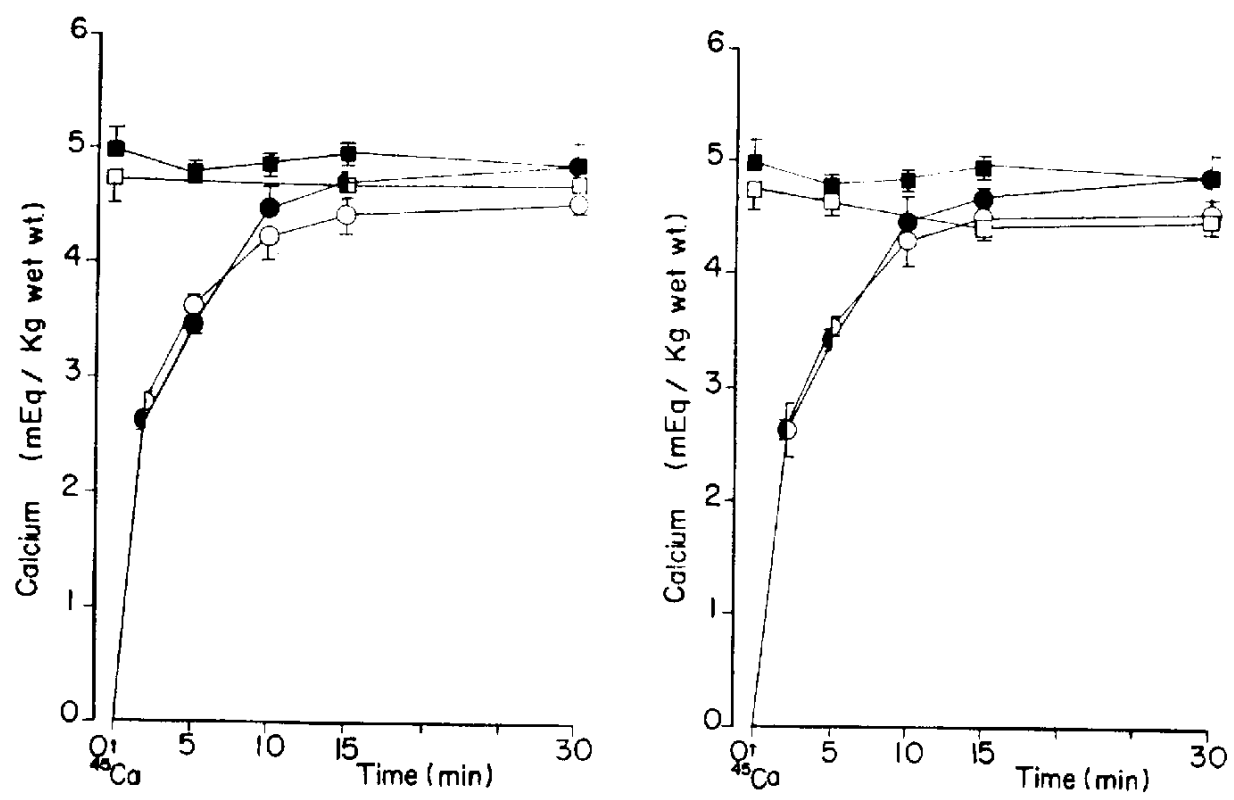

FIG. 3. Changes in tissue $\mathrm{Ca}$ and ${ }^{45} \mathrm{Ca}$ uptake in the presence of $3.3 \times 10^{-6} \mathrm{M}$ tripelennamine (left) or $5.4 \times 10^{-6} \mathrm{M}$ histamine and tripelennamine (right).

Tissue Ca ( $\mid 7),{ }^{45} \mathrm{Ca}$ uptake $(O)$ in Tyrode solution without (filled symbols) and with drugs (open symbols).

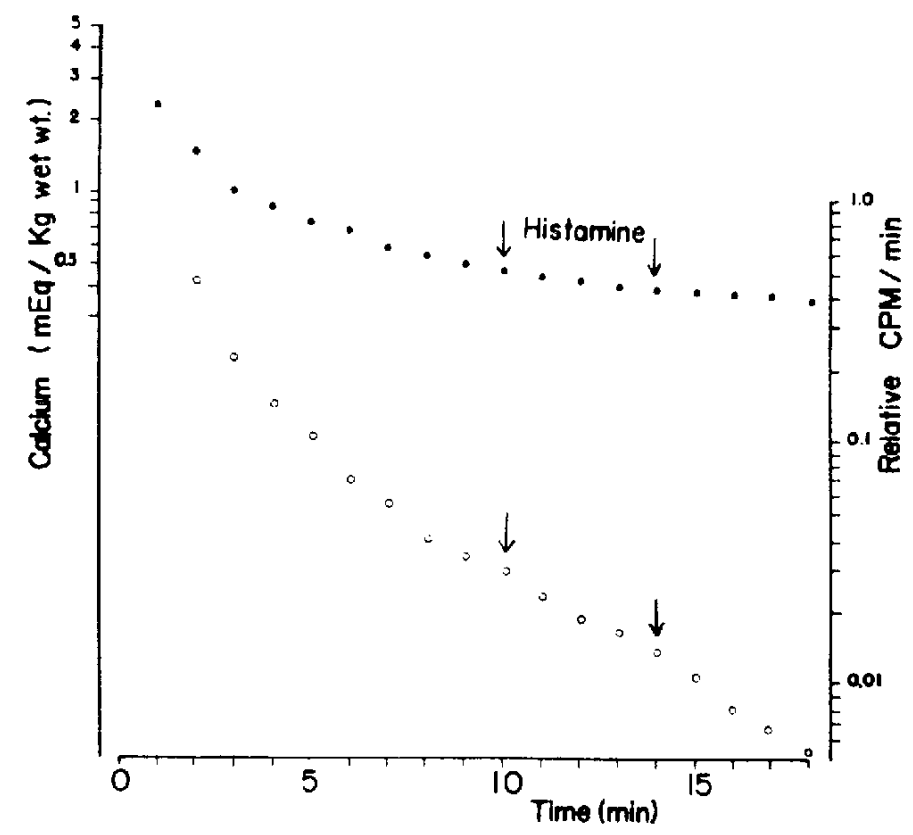

FIG, 4. Effect of histamine on the efflux of ${ }^{45} \mathrm{Ca}$ from taenia coli.

Upper curve : Amount of radioactivity in the muscle (left ordinate).

Lower curve : Rate of ${ }^{45} \mathrm{Ca}$ efflux (right ordinate).

$5.4 \times 10^{-6} \mathrm{M}$ histamine was added between two arrows. 


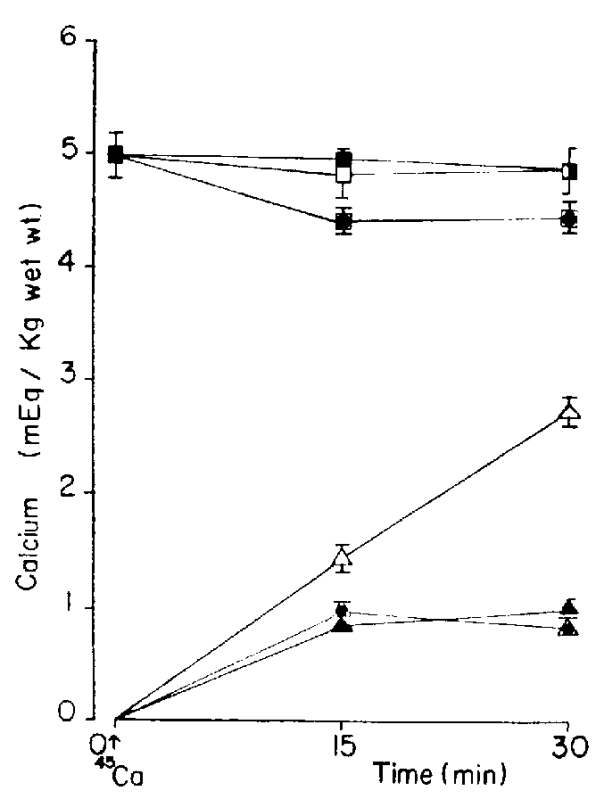

FIG. 5. Changes in tissue $\mathrm{Ca}$ and TBF in the presence of histamine or histamine and tripelennamine.

$\begin{array}{lcc}\text { Conditions } & \text { Tissue Ca } & \text { TBF } \\ \begin{array}{l}\text { Control } \\ \text { Histamine }\end{array} & \square & \triangle \\ \begin{array}{l}\text { Histamine and } \\ \text { tripelennamine }\end{array} & & \triangle\end{array}$

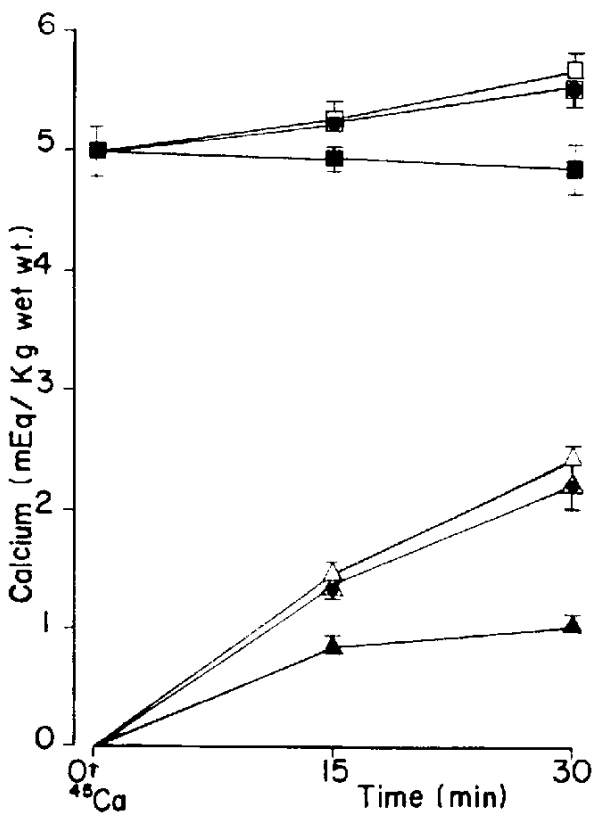

FIG. 6. Changes in tissue $\mathrm{Ca}$ and TBF in the presence of high-K solution or high-K solution with tripelennamine. Conditions Tissue Ca TBF

Control

High-K solution

High-K solution with tripelennamine

Tissue Ca TBF

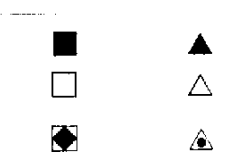

tion in the presence or absence of histamine under tripelennamine treatment (Fig. 3).

"Ca efflux: In the presence of histamine, no significant change was observed on the curves showing the rate of ${ }^{43} \mathrm{Ca}$ efflux and the amount of radioactivity remaining in the muscle (Fig. 4).

Tightly bound fraction $(T B F)$ : Fig. 5 and 6 show the changes in TBF of the muscle. The size of TBF after 30 minutes incubation was $1.0 \pm 0.1 \mathrm{mEq} / \mathrm{Kg}$ wet tissue (24) in normal Tyrode solution and increased to $2.7 \pm 0.2 \mathrm{mEq} / \mathrm{kg}(6)$ in histamine-added solution and to $2.4 \pm 0.1 \mathrm{mEq} / \mathrm{Kg}(7)$ in high-K solution.

When the muscle was pretreated with tripelennamine, histamine did not develop tension and the size of TBF stayed at the control level (Fig. 5). However, the tripelennamine pretreatment did not alter the increase in the size of TBF of the muscle treated with high-K solution (Fig. 6).

Exiracellular space: The extracellular space measured with ${ }^{14} \mathrm{C}$-sorbitol was $36.3 . t$ $0.9 \%(7)$ in normal Tyrode solution. When muscles were incubated with histamine or histamine and tripelennamine, the extracellular space was $34.8 \pm 1.7 \%(7)$ and $34.1 \pm 1.2 \%$ (8), respectively. The extracellular space was scarcely influenced by histamine or histamine and tripelennamine.

These results were schematically summarized in Fig. 7. 


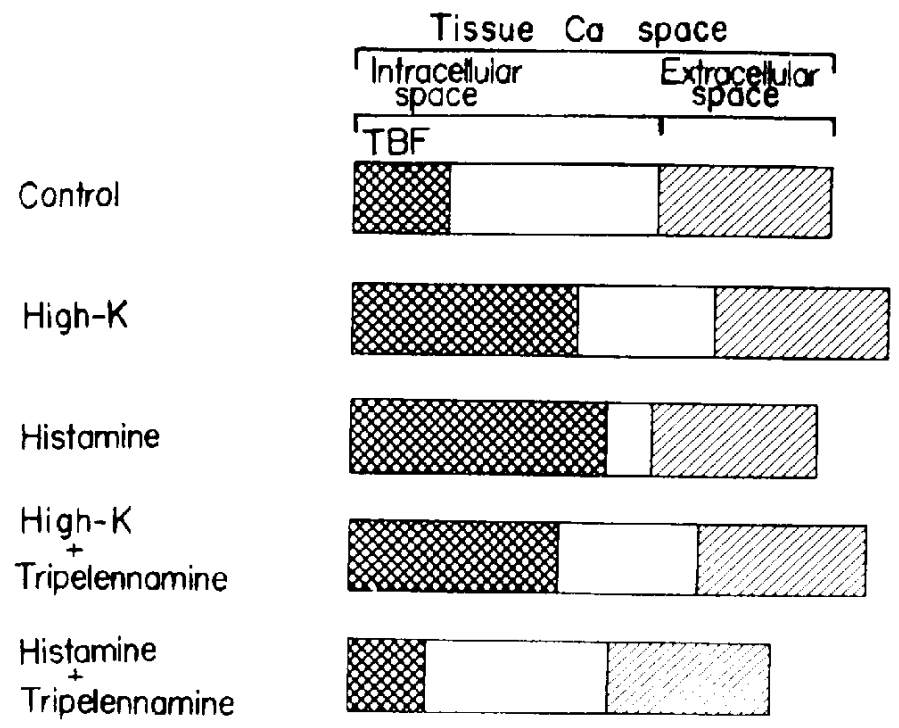

FIG. 7. Schematic arrangement of $\mathrm{Ca}$ spaces in taenia coli under various conditions. Size of TBF is superimposed upon the column of intracellular space.

\section{DISCUSSION}

Histamine induced a tonic contraction and increased the size of TBF but did not affect tissue $\mathrm{Ca}$ content or $\mathrm{Ca}$ fluxes in taenia coli. The slight depress in ${ }^{45} \mathrm{Ca}$ uptake observed 30 minutes after the addition of histamine may reflect the increase in the size of $\mathrm{TBF}$, i.e., the increase in slowly exchanging $\mathrm{Ca}$ fraction in the tissue. Tripelennamine treatment of the muscle abolished both histamine-induced contraction and the increase in the size of TBF. From the above data, it is suggested that loosely bound cellular $\mathrm{Ca}$ moves towards tightly bound Ca fraction during histamine induced contraction of taenia coli.

In the case of high-K induced tonic contraction, it has been reported that both $\mathrm{Ca}$ influx and tissue $\mathrm{Ca}$ content increased and the $\mathrm{Ca}$ ion taken up in the cell moved towards TBF $(2,3)$. On the other hand, during $\mathrm{Ba}$ induced tonic response, although tissue $\mathrm{Ca}$ content remained unchanged and both fluxes decreased, cellular $\mathrm{Ca}$ moved towards TBF within the cell (3). Comparing these and the present data, the changes in tissue Ca contents and $\mathrm{Ca}$ fluxes are rather conflicting during the tonic contractions induced by these smooth muscle stimulants. Similar observations have been reviewed by Lüllmann (I) on the smooth muscles in the presence of various stimulants and relaxants. However, the presence of the correlation between tension development and the size of TBF has atready been suggested ( $3-5$ ) and the present data also supports this.

The examination of time courses of the increase in tension development and the size of TBF shows that the tension reaches almost maximal level soon after the addition of histamine and maintained at a steady level, but the size of TBF increased gradually during the period. The similar time courses have been observed in the cases of high-K and Ba induced tension developments (3). Further, it was observed that although the tonic 
tension development in high-K solution declined within one minute when the medium was replaced with normal Tyrode solution, the increased size of TBF decreased gradually to the control level within 15 minutes (unpublished data), suggesting that there is no direct correlation between tension and the size of TBF.

From these data, it may be proposed that the increased intracellular $\mathrm{Ca}$ ions resulted from the increase in $\mathrm{Ca}$ influx by high- $\mathrm{K}$ solution or from the release of bound $\mathrm{Ca}$ by histamine or $\mathrm{Ba}$ interact with contractile protein to induce contraction, from which the $\mathrm{Ca}$ ion is taken up continuously by TBF to maintain contraction.

The tension development in taenia coli by histamine was accompanied by a proportional increase in the rate of oxygen consumption, both of which were abolished by antihistamine, the relation between oxygen consumption and $\mathrm{Ca}$ movement in the presence of histamine will be reported and discussed in detail in the following paper (9).

\section{SUMMARY}

The eflect of $5.4 \times 10^{-6} \mathrm{M}$ histamine on Ca exchange was investigated in guinea pig taenia coli.

1. In the presence of histamine, Ca content, ${ }^{45} \mathrm{Ca}$ uptake and ${ }^{45} \mathrm{Ca}$ effiux did not differ considerably from control value, but the size of cellular Ca fraction which did not exchange within 4 minutes (tightly bound fraction, TBF) increased.

2. When the muscle was pretreated with $3.3 \times 10^{-5} \mathrm{M}$ tripclennamine, histamine did not induce contraction and the size of TBF was maintained at the control value. The pretreatment with tripelennamine did not alter the increments in tension, tissue $\mathrm{Ca}$ content and TBF by high-K solution.

3. It may be suggested that histamine releases loosely bound cellular $\mathrm{Ca}$ and, at least, a part of the Ca ions interact with contractile protein to induce contraction, from which $\mathrm{Ca}$ is taken up continuously by TBF to maintain contraction.

Acknowledgement: Our thanks are due to Mr. Shuji Tsuda in our Department for his helpful critisism on this work.

\section{REFERENCES}

1) Lïllmann, H.: Smooth Muscle, Edited by Bïlaring, E. et al., p. 151, Edward Arnold (Publishers) Ltd, London (1970)

2) Urakawa, N. and lolland, W.C.: Am. J. Physiol. 207, 873 (1964)

3) Karaki, H., Iklda, M. and Urakawa, N.: Jap. J. Pharmac. 19, 291 (1969)

4) Urakawa, N., Karaki, H. and Ikeda, M.: Jap. J. Pharmac. 20, 360 (1970)

5) Karaki, H., Ikeda, M. and Urakawa, N.: Jap. J. Pharmac. 20, 530 (1970)

6) Nasu, T., Karaki, H., Ikeda, M. and Urakawn, N.: Jap. J. Pharmac. 20, 603 (1970) (Short communication)

7) GoOdFord, P.J.: J. Physiol. 176, 180 (1965)

8) Aкulue, P.I.: Br. J. Pharmac. Chemother. 27, 347 (1966)

9) Saito, Y., Sakal, Y., Ikeda, M. and Urakawa, N.: Jap. J. Pharmac. 21, 605 